\title{
Fossils, Feeding, and the Evolution of Complex Multicellularity
}

\section{Citation}

Knoll, Andrew H., and Daniel J.G. Lahr. 2016. "Fossils, feeding, and the evolution of complex multicellularity." In Multicellularity, Origins and Evolution, The Vienna Series in Theoretical Biology, eds. Karl J. Niklas and Stuart A. Newman. Cambridge, MA: MIT Press.

\section{Published Version}

https://mitpress.mit.edu/books/multicellularity

\section{Permanent link}

http://nrs.harvard.edu/urn-3:HUL.InstRepos:34390340

\section{Terms of Use}

This article was downloaded from Harvard University's DASH repository, and is made available under the terms and conditions applicable to Open Access Policy Articles, as set forth at http:// nrs.harvard.edu/urn-3:HUL.InstRepos:dash.current.terms-of-use\#OAP

\section{Share Your Story}

The Harvard community has made this article openly available.

Please share how this access benefits you. Submit a story.

Accessibility 


\section{Fossils, Feeding, and the Evolution of Complex Multicellularity}

\section{Andrew H. Knoll and Daniel J. G. Lahr}

\section{Andrew H. Knoll}

Department of Organismic and Evolutionary Biology, Harvard University

\section{Daniel J.G. Lahr}

Department of Zoology, Institute of Biosciences, University of São Paulo

The evolution of complex multicellularity is commonly viewed as a series of genomic events with developmental consequences. It is surely that, but a focus on feeding encourages us to view it, as well, in terms of functional events with ecological consequences. And fossils remind us that these events are also historical, with environmental constraints and consequences.

Several definitions of complex multicelluarity are possible; here we adopt to view that complex multicellular organisms are those with tissues or organs that permit bulk nutrient and gas transport, thereby circumventing the limitations of diffusion (Knoll, 2011). Organisms that fit this description occur exclusively in eukaryotic clades, and so we begin by tracing the early evolution of eukaryotes, based on the fossil record but informed by phylogeny and environmental geochemistry. In particular, we ask: what might have facilitated a major increase in eukaryotic diversity, documented in the geologic record ca. 800 million years ago? By analogy to explanations for the Cambrian radiation of animals, we hypothesize that the origin or 
expansion of eukaryovory - protists ingesting other protists - can account, at least in part, for the observed historical record. Insofar as simple multicellularity can provide protection from eukaryovorous predators, molecular clocks that place the origin of animals in this same time frame may also find at least partial explanation in the ecological consequences of novel feeding modes. More broadly, mapping feeding mode onto a modern framework for eukaryotic phylogeny suggests that escape from phagotrophy was a prerequisite for the evolution of complex multicellular organisms. That stated, physical changes in the Earth system also influenced the Ediacaran/Cambrian radiation of animals and need to be taken into account in the construction of historical narratives.

\section{A brief history of early eukaryotic evolution}

The identification of ancient microfossils as eukaryotic can be challenging, as neither DNA nor histological details are preserved in the deep sedimentary record. What preserves are cell walls, imparting an immediate bias to the microfossil record - protistan fossils will be restricted to those groups that synthesize preservable cell walls at some stage of their life cycles (Knoll 2014). Under favorable circumstances, lipids can also be preserved, and steranes (the geologically stable derivatives of sterols) provide a molecular account of eukaryotic evolution that complements the conventional record of body fossils (e.g., Summons and Lincoln 2012).

In combination, large size, complex morphology, and complex ultrastructure as revealed by TEM provide strong evidence of eukaryotic origin, and microfossils that meet this criterion occur in rocks as old as 1600-1800 Ma (Knoll et al. 2006). None of these microfossils can be assigned with confidence to an extant subclade of the Eukarya and, indeed, molecular clock 
estimates suggest that some or all could be stem group eukaryotes (e.g., Parfrey et al. 2011; Eme et al. 2014).

Two examples illustrate what can and cannot be inferred from early eukaryotic microfossils. Shiuyousphaeridium macroreticulatum is a large $(110-180 \mu \mathrm{m})$ ellipsoidal vesicle that bears many symmetrically distributed cylindrical processes, as well as tessellated $2 \mu \mathrm{m}$ fields that cover the vesicle surface (Fig. 1A); TEM shows a complex multilayered wall ultrastructure (Xiao et al 1997; Javaux et al. 2004). As Cavalier-Smith (2002) remarked, “Cysts with spines or reticulate surface sculpturing would probably have required both an endomembrane system and a cytoskeleton, the most fundamental features of the eukaryotic cell, for their construction.” Shiuyousphaeridium is thus interpreted with confidence as eukaryotic, but it cannot be assigned to a specific clade within the domain. Functional interpretation is also possible: Shiuyousphaeridium is the preserved wall of a resting cell, or cyst. Therefore, in addition to a dynamic cytoskeleton/membrane system, the Shiuyousphaeridium organism had a life cycle that included cell differentiation, a key character in the later evolution of complex multicellularity (Mikhailov et al. 2009). How old are these fossils? Their age is constrained by radiometric dating to be older than 1400 million years but younger than 1700 million years (Lan et al. 2014).

Other fossils of comparable age add nuance to this picture. Tappania plana (Fig.1B) is a morphologically complex microfossil found in 1400-1600 million year old shales from Australia, China, India, Siberia, and North America (Yin 1997; Xiao et al. 1997; Javaux and Knoll 2015). Tappania specimens are up to $150 \mu \mathrm{m}$ in diameter and bear a limited number of cylindrical extensions that emerge asymmetrically from the vesicle surface; the extensions sometimes show evidence of dichotomous branching, suggesting an actively metabolizing cell that grew finger- 
like extensions, changing its shape in real time. Like Shiuyousphaeridium, Tappania was eukaryotic but cannot easily be assigned to an extant eukaryotic clade. Tappania does, however, document two features that underpin complex multicellularity: cell polarity and, again, the dynamic cytoskeleton/membrane system (Knoll et al. 2006; Javaux 2011). Among living eukaryotes, actively metabolizing cells with preservable cell walls tend to be either photosynthetic or osmotrophic, along with mixotrophs such as dinoflagellates. Many protists are capable of taking in organic molecules, and a few clades, notably the fungi and oomycetes, gain nutrition primarily by elaborating cylindrical projections to facilitate feeding by absorption. Oomycetes and fungi are widely separated in terms of phylogeny, and molecular clocks discourage interpretation of Tappania as either one, but functionally, these fossils seem to indicate the early differentiation of osmotrophy as a principal feeding mode within the Eukarya.

In general, late Paleoproterozoic and Mesoproterozoic eukaryotes are problematic microfossils that occur in limited diversity within sedimentary rocks deposited beneath coastal oceans. Molecular fossils, in turn, suggest that in these oceans, bacteria were the principal sources of primary production (Brocks et al. 2005). By 1100-1200 million years ago, however, large populations of the early-branching red alga Bangiomorpha (Butterfield 2000) simultaneously document the presence of an extant eukaryotic clade, simple multicellularity, and the emergence of photosynthesis as a major feeding mode within the Eukarya.

\section{Feeding Mode and Neoproterozoic Protistan Diversification}

Fossils suggest that an important change in eukaryotic diversity occurred around 800 million years ago (Knoll 2014). New and distinctive organic-walled protists enter the record 
(Fig. 1E; Butterfield et al. 1994; Butterfield 2005a,b), diversity expands among simple multicellular and coenocytic forms (Butterfield et al. 1994; Butterfield 2004, 2009), diverse protists with vase-shaped tests proliferate globally (Fig. 1C; Porter et al. 2003; Strauss et al. 2014), unusually diverse assemblages of scale microfossils occur locally in northwestern Canada (Fig. 1D; Cohen and Knoll, 2012), and steranes suggest the rising ecological importance of algae as primary producers in marine environments (Summons et al. 1988; Ventura et al., 2005). How might we explain the paleontologically observed diversification of eukaryotes so long after the origin of the group?

A working hypothesis is inspired by another radiation that occurred 250 million years later - the Cambrian explosion of animal diversity (Erwin and Valentine 2013). For many years, Cambrian radiation has been viewed as driven, at least in part, by the emergence of carnivores that initiated an evolutionary arms race among predators and prey (e.g., Stanley 1973). The logic of this argument can be extended naturally to the microscopic world of protists. The last common ancestor of extant eukaryotes was a phagotrophic cell that ingested bacteria-sized particles (Cavalier Smith 2013; see below). In principle, then, the mid-Neoproterozoic origin or expansion of protists that feed on other protists could have set in motion an earlier arms race, resulting in accelerated eukaryotic diversification (Porter 2011; Knoll 2014).

Fossils provide both direct and inferential support for the eukaryovory hypothesis. Vaseshaped microfossils, which preserve easily and so have first appearances in the fossil record that at least broadly approximate their evolutionary origins, have never been observed in rocks older than about 800 million years, but are among the most common fossils in 800-740 Ma sedimentary successions observed globally (Strauss et al. 2014; agglutinated tests have also been reported from ca. 660-670 million year old carbonates in Namibia and Mongolia, Bosak et al. 
2011, Dalton et al. 2013). These fossils provide three lines of evidence consistent with the eukaryovory hypothesis. First, at least some Neoproterozoic vase-shaped microfossil populations closely resemble the tests of extant arcellinid amoebozoans, a diverse group of bacterivorous and eukaryorous protists (Porter et al. 2003). Second, the emergence of testate protists in marine environments needs functional explanation, and reasonable conjecture holds that the organic walled (in some cases likely scale-encrusted; Porter and Knoll 2000) tests provided defense against protistan predators. And third, vase-shaped microfossils from shales exposed deep within the Grand Canyon, Arizona, sometimes have regular half-moon holes cut out of the test wall (Porter et al. 2003). Such features are not easily explained as diagenetic structures; more likely they provide a direct record of predation by vampyrellid or other eukaryovorous protists in the local community (Porter et al. 2003, Hess et al. 2012).

Ca. 800 million year old limestones of the Fifteenmile Group, northwestern Canada, contain a remarkable abundance of biogenic scales preserved by phosphate mineralization (Cohen and Knoll 2012). Some forty distinct taxa have been identified, and while none can be assigned to an extant taxonomic group with confidence, they generally resemble the organic and siliceous scales that armor the walls of some prymnesiophytes, ciliates, centrohelid heliozoans, rhizarians, chrysophytes, and green algae. Again, defense against protistan predators provides a reasonable, if not unique, interpretation of Neoproterozoic scale synthesis.

Molecular fossils independently document eukaryotic expansion. For example, gammacerane (a geologically stable derivative of tetrahymanol) records the presence of ciliates, a clade rich in eukaryovorous species (Summons et al., 1988), while steranes indicate the growing importance of green and red algae as primary producers along continental shelves (Summons et al. 1988; Knoll et al. 2007). We note that the genes required for tetrahymanol 
synthesis have spread through the Eukarya by horizontal transfer (Takashita et al. 2012), but gene trees suggest that ciliate genes are sister to all others. Thus, if gammacerane is present in sedimentary rocks, ciliates existed at the time those rocks formed. Limited experiments also support the view that eukaryovory might have facilitated the rise to ecological prominence of eukaryotic algae. For example, when Ratti et al. (2013) grew eukaryotic algae in the presence of ciliate predators, both specific growth rate and protein content increased; cyanobacteria subjected to the same treatment showed either no response or decreased specific growth rates.

At present, then, the hypothesis that eukaryovory spurred Neoproterozoic protistan diversification can be supported from a number of paleontological perspectives. Intriguingly, molecular clocks suggest that animals differentiated as part of this Neoproterozoic diversification (Erwin et al. 2011). Could eukaryovory, then, be relevant to the origins of animal multicellularity? It could, and in a direct way. Experiments (e.g., Boraas et al. 1998, see also Hessen and van Donk 1993) show that protistan predators can induce multicellularity in previously unicellular algal populations - there is strong selection pressure because the predators are not capable of phagocytosing the larger, multicellular individuals. The late NeoproterozoicCambrian expansion of complex multicellularity and complex macroscopic coenocytes in both green and red algae (Butterfield 2009a; Xiao et al. 2002; Yuan et al. 2011) might also reflect both eukaryovory and the subsequent radiation of animal grazers.

Alegado et al. (2012) have hypothesized that simple multicellularity could actually enhance capture of prey bacteria in choanoflagellates, and other functional advantages of simple multicellularity are possible (e.g., Knoll 2011; Parfrey and Lahr 2013). And Butterfield (2014) has suggested that nascent metazoans themselves provided the ecological spark for Neoproterozoic eukaryotic diversification. This interpretation relies on the phylogeny and 
molecular clock estimate of Erwin et al. (2011), which view sponges as both basal and paraphyletic, but it is far from obvious why the emergence of filter feeding by sponges would facilitate the patterns of morphological diversification actually observed in the fossil record. An alternative version of this hypothesis would ascribe protistan diversification to predation by tiny ancestral bilaterians -- which differs from the "straight eukaryovory” hypothesis more in degree than in kind. A number of distinct feedbacks are possible between early metazoans and protists, and in all probability most were in play in Neoproterozoic oceans. Whether by avoiding or enhancing prey capture, feeding mode provides an illuminating functional perspective on the emergence of complex multicellular organisms in Neoproterozoic oceans.

\section{You are how you eat}

To place arguments about feeding mode and its evolutionary consequences into phylogenetic context, we performed analyses of trait evolution over samples of available phylogenetic trees. Details of data sets and methodologies are found in Lahr and Knoll (in review); here we present only a brief summary of methods and results in this paper (Fig. 2).

We began with the files used to generate the dated phylogeny of Parfrey et al. (2011). We used both the 1000 bootstrapped trees generated by their Maximum Likelihood analysis and the over 1000 trees sampled in each of 7 independent Bayesian searches. These collections of trees provide a sample of the most probable topology and branch lengths, given the data, and enable assessment of uncertainty while generating probabilities for specific patterns of trait evolution. In order to reconstruct the ancestral states for selected nodes (i.e. hypothetical ancestors), we scanned the literature to determine the feeding mode in each terminal taxon 
originally used by Parfrey et al. (2011). Specifically, we characterized the primary feeding mode of each terminal taxon as osmotrophy, autotrophy, bacteriovory, and/or eukaryovory. Finally, we calculated the probabilities of each particular feeding mode for nodes within the phylogeny using the program BayesTraits. Combinations are possible, for the example, the mixotrophy found in photosynthetic dinoflagellates (Joeng et al. 2010). The reconstruction of an ancestral state that has equally shared probabilities for each of the four feeding modes may thus be interpreted either as an ancestor that could do everything, or, perhaps more likely, as simply uncertainty in the reconstruction.

Such an exercise comes with several potential pitfalls. First, the phylogeny itself may be uncertain (or wrong), which can result in incorrect estimates of ancestral character states. Second, the taxa used to construct the phylogeny may not capture the range of feeding modes found on any particular branch of the tree - that is, fuller sampling of a clade might alter the probability of ancestral feeding mode for a clade. To address these issues, we revisited the major clades of the eukaryotic tree, using other published phylogenies containing several taxa not employed by Parfrey et al. (2011). In particular, we tested the same approach using the phylogenetic framework for amoebozoans published in Lahr et al. (2013), opisthokonts (based on the phylogenetic framework of Paps et al. (2013) and Rhizaria (based on Sierra et al. 2013). Moreover, we tested our conclusions for ancestral feeding mode in the Excavata and Archaeplastida, finding them to be in agreement with results from other analyses (Cavalier Smith 2013 and Deschamps and Moreira 2009, respectively). The summary figure shown here provides a composite of results from these multiple analyses (Fig. 2).

Consistent with earlier opinion (e.g., Cavalier Smith 2013), placement of the root to the eukaryotic tree between opisthokonts + amoebozoans and everything else (the unikont root) or 
within or near the excavates (excavate root) suggests that that the last common ancestor of extant eukaryotes was a bacterivorous phagotroph (Lahr and Knoll, in review). Interestingly, however, placement of the root between opisthokonts and all other eukaryotes (the ophisthokont root) suggests that the last common ancestor could have been osmotrophic (see discussion below). In any case, eukaryovory is a derived feeding mode, found principally within a limited number of protistan clades. The SAR clade may have evolved eukaryovory in its earliest representatives, but the ecologically dominant clades of eukaryovorus SAR protists - ciliates, dinoflagellates, and foraminiferans have Neoproterozoic origins (Parfrey et al. 2011; Eme et al. 2014; Groussin et al. 2011). Eukaryovorous amoebozoans also diversified during the Neoproterozoic Eon (Parfrey et al. 2011).

Integrating feeding mode with molecular clocks, then, provides further support for the eukaryovory hypothesis to explain Neoproterozoic eukaryotic diversification. Another interesting result also derives from this analysis. No complex multicellular organisms occur within phagotrophic clades. The paucity of even simple multicellular species among phagotrophic protists was noted earlier by Baker (1948; see Bonner, this volume), who attributed this to the specific feeding requirements of phagotrophs. Whether for this alone or for additional reasons, the cell biological requirements for phagotrophy are inconsistent with the formation of functionally differentiated tissues. Thus, complex multicellularity evolved several times within photosynthetic clades (green algae, florideophyte red algae, and laminarialean brown algae) and in osmotrophs (ascomycetes and basidiomycete fungi, eumetazoan animals). That is, complex multicellularity appears to accompany the functional escape from phagotrophy.

In this regard, the evolution of osmotrophy in eumetazoans stands as a defining moment in animal evolution. While the phylogenetic relationships of early branching animals remain 
uncertain, there is reason to believe that the earliest animals were bacterivorous, like most sponges and choanoflagellates, (Adamska, this volume). Eumetazoans feed primarily by secreting extracellular digestive enzymes and then absorbing metabolizable molecules. Placozoans are little differentiated beyond upper and lower epithelia, but are capable of taking up nutrients via both extracellular digestion and the phagocytosis of entire cells (through both epithelia; Wenderoth 1986; Srivastava et al. 2008). Cnidarians and bilaterian animals, in turn, have a differentiated gut cavity to localize this function. Something approaching consensus now suggests that many of the familiar quilt-like forms of the macroscopic Ediacaran biota (580-541 million years old) reflect an early stage in the evolution of eumetazoan osmotrophy, before body plan reorganizaton led to a differentiated digestive system (e.g., Sperling et al., 2009; LaFlamme et al. 2009; Cuthill and Conway Morris 2014). Filasterea, the clade that is sister to animals + choanoflagellates contains phagotophs that consume bacteria and small eukaryotes. Thus, osmotrophy is derived within this opisthokont branch. Intriguingly, Corallochytrium and the ichythosporeans are osmotrophs.

Fungi are also osmotrophs, but their sister group, containing Fonticula and Nuclearia, is bacterivorous, and the resulting uncertainty of feeding mode in their common ancestor plays a key role in governing the root dependency of the ancestral feeding mode within eukaryotes as a whole. It remains to be seen whether the probabilities of specific feeding mode changes are all equal, but accepting the last common ancestor of opisthokonts as a bacterivore, osmotrophy must have evolved at least three times within this supergroup. Regardless of the proper history of feeding mode evolution, however, opisthokonts support the general conclusion that complex multicellularity occurs in eukaryotic clades characterized by osmotrophy or photosynthesis. 


\section{Physical environment also matters}

The preceding arguments suggest that feeding mode played several key roles in the evolution of multicellular organisms in early oceans, providing both selective pressures favoring multicellular organization and cell biological constraints on multicellular organization. This does not, however, mean that physical environment was irrelevant. Historically, the emergence of large animals has been linked mechanistically to rising oxygen tensions in the atmosphere and oceans (summarized by Mills and Canfield 2014). In recent years, the oxygen facilitation hypothesis has been challenged on several fronts (e.g., Butterfield 2009b), but stratigraphic evidence still shows a correlation in time between the paleontological record of animal diversification and geochemical indications of change in global redox conditions (Lyons et al. 2014). Both ecological surveys of present day oxygen minimum zones (summarized by Sperling et al., 2013a,b) and physiological experiments on sponges (Mills et al., 2014) make it clear that small and anatomically simple animals could have originated when $\mathrm{pO}_{2}$ was as low as 1-4 \% of present atmospheric levels (PAL), consistent with atmospheric compositions traditionally accepted for 800 million years ago. Larger animals with derived feeding modes may, however, have been inhibited until $\mathrm{pO}_{2}$ rose to higher levels, as inferred from the chemistry of Ediacaran sedimentary rocks. Sperling et al. (2013b) reconciled decades of debate about ecological versus environmental drivers of metazoan evolution by showing that carnivory, the feeding mode thought to have initiated an evolutionary arms race in Cambrian oceans (e.g., Stanley 1973) requires more oxygen than other metazoan feeding strategies. Thus, it appears that increasing oxygen availability in Ediacaran and Cambrian oceans could have set ecological drivers of metazoan diversification in motion. 
Oxygen facilitation scenarios depend as much on low pre-Ediacaran oxygen levels as they do subsequent higher $\mathrm{pO}_{2}$ (Mills and Canfield 2014). If $\mathrm{pO}_{2}$ reached levels of, say, $10 \%$ PAL well before the Ediacaran Period, hypotheses of oxygen facilitation would be falsified. If, however, earlier Proterozoic oxygen levels hovered around 1\% PAL, then oxygen facilitation would remain a viable hypothesis for both the origin of animals and the later expansion of large animals, including carnivores. Planavsky et al. (2014) have recently argued on the basis of chromium isotope geochemistry that $\mathrm{pO}_{2}$ was as low as $0.1 \% \mathrm{PAL}$ until ca. 800 million years ago. This result is new and sure to attract critical attention, but even if it is off by an order of magnitude, the role of oxygen in animal evolution would be supported strongly.

Might the earlier expansion of eukaryovory similarly reflect environmental facilitation? Such a view is consistent with the phylogenetic inference that eukaryovory evolved independently in several clades during the Neoproterozoic Era. It is also consistent with arguments based on oxygen demand. In animals, the oxygen requirements for carnivory are thought to reflect, at least in part, the transiently high oxygen demand of digesting large prey (Sperling et al. 2013b). Logically, the oxygen demand of ingesting a $10 \mu \mathrm{m}$ protistan cell would be three orders of magnitude higher than that incurred by phagocytosing a $1 \mu \mathrm{m}$ bacterial cell, and so even the modest increase in $\mathrm{pO}_{2}$ inferred by Planavsky et al. (2014; see also Frei et al. 2009) for the Neoproterozoic Earth could have facilitated the ingestion of larger cells. Without question, experimental insights and improved geochemical resolution of redox history will both be needed to evaluate such hypotheses.

\section{Conclusions}


John Tyler Bonner has long underscored the importance of feeding in the evolution of multicellular organisms, not least in his preface to this volume (Bonner, this volume), and our results further support the need for functional perspective on this grand evolutionary issue. The fossil record of early eukaryotic evolution provides insights into the acquisition of cell biological characters thought to play an important role in the evolution of complex multicellularity. It also inspires an ecological hypothesis for Neoproterozoic protistan diversification that focuses on eukaryotic feeding mode and its diversification through time. Phylogenetic perspectives on feeding mode evolution complement paleontological evidence in favor of this hypothesis and also highlight the importance of feeding mode for the probability of evolving complex multicellularity within any given clade. Improved phylogenetic exploration of feeding mode, continuing paleontological discovery, better resolution of geochemical proxies for redox evolution, and novel physiological experimentation will collectively help to test and refine hypotheses that aim to place the evolution of multicellular organisms into its proper functional, ecological and paleoenvironmental context.

\section{Acknowledgments}

We thank Karl Niklas and Stuart Newman for the invitation to participate in a stimulating workshop at KLI, and we thank Erik Sperling and Pete Girguis for discussion. AHK was supported by the NASA Astrobiology Institute; DJGL is supported by a FAPESP Young Investigator Award (2013/04585-3). 


\section{Figure Legends}

Figure 1: Proterozoic eukaryotes. A. Shuiyousphaeridium macroreticulatum, the 1400-1700 million year old Ruyang Group, China. B. Tappania plana, the 1400-1500 million year old Roper Group, Australia. C. Bonniea dacruchares, the ca. 750 million year old Chuar Group, Arizona. D. Thorakidictyon myriocanthum, the ca. 800 million year old Fifteenmile Group, Canada. E. Trachyhystrichosphaera polaris, 750-800 million year old Svanbergfjellet Formtion, Spitsbergen. (Bar in $\mathrm{D}=40$ microns for $\mathrm{A},=50$ microns for $\mathrm{B},=20$ microns for $\mathrm{C},=14$ microns for D, and = 100 microns for E.0

Figure 2: A summary of the evolution of carbon uptake mechanisms in eukaryotes, based on character trait analyses. The cartoon was constructed based on several distinct analyses detailed in Lahr and Knoll (in review). The backbone of the tree is based on the Parfrey et al. (2011) reconstruction, except for relationships within the SAR clade and Opisthokont clades, grafted from Sierra et al. (2013) and Paps et al. (2013), repsectively. The plotted probabilities are based on Maximum Likelihood reconstruction of character trait evolution based on the respective trees, with terminal states obtained from a large body of literature. An opisthokont rooting was used for the traits plotted on this tree, with the exception that we show what the ancestral eukaryote would look like if the rooting was unikont-based. Branch lengths are not to scale; that is, they do not reflect evolutionary or real time. 


\section{References}

Adamska this volume

Alegado, R.A., L.W. Brown, S. Cao, R.K. Dermenjian, R. Zuzow, S.R. Fairclough, J. Clardy, and N. King. (2012). Bacterial sulfonolipid triggers multicellular development in the closest living relatives of animals. ELIFE 1: Article Number: UNSP e00013.

Baker,J.R. (1948) The status of the protozoa. Nature 161: 548-551,

Bonner, J.T. (2015). The evolution of multicellularity. This volume.

Boraas, M.E., D.B. Seale, and J.E. Boxhorn. (1998). Phagotrophy by a flagellate selects for colonial prey: a possible origin of multicellularity. Evolutionary Ecology 12: 153—64.

Bosak, T., D.J.G. Lahr, S.B. Pruss, F.A. Macdonald, L. Dalton, and E. Matys. (2011). Agglutinated tests in post-Sturtian cap carbonates of Namibia and Mongolia. Earth and Planetary Science Letters 308: 29-40.

Brocks, J.J., G.D. Love, R.E. Summons, A.H. Knoll, G.A. Logan, and S. Bowden. (2005). Biomarker evidence for green and purple sulfur bacteria in an intensely stratified Paleoproterozoic ocean. Nature 437: 866-870.

Butterfield, N.J. (2000). Bangiomorpha pubescens n. gen., n. sp.: implications for the evolution of sex, multicellularity and the Mesoproterozoic/Neoproterozoic radiation of eukaryotes. Paleobiology 26: 386-404.

Butterfield, N.J. (2004). A vaucheriacean alga from the middle Neoproterozoic of Spitsbergen: implications for the evolution of Proterozoic eukaryotes and the Cambrian explosion.

Paleobiology 30: 231--52

Butterfield, N.J. (2005a). Reconstructing a complex early Neoproterozoic eukaryote, Wynniatt Formation, arctic Canada. Lethaia 38:155--69

Butterfield, N.J. (2005b). Probable Proterozoic fungi. Paleobiology 31:165--82

Butterfield, N.J. (2009a). Modes of pre-Ediacaran multicellularity. Precambrian Research 173:201-11

Butterfield, N.J. (2009b). Oxygen, animals and oceanic ventilation: an alternative view Geobiology 7: 1-7

Butterfield, N.J. (2014). Early evolution of the Eukaryota. Palaeontology doi:1111/pala.12139.

Butterfield, N.J., A.H. Knoll, and K. Swett. (1994). Paleobiology of the Neoproterozoic Svanbergfjellet Formation, Spitsbergen. Fossils and Strata 34: 1-84. 
Cavalier Smith, T. (2002). The neomuran origin of archaebacteria: the negibacteria root of the universal tree and bacteria megaclassification. International Journal of Systematic Microbiology 52: 7-76.

Cavalier Smith, T. (2013). Early evolution of eukaryote feeding modes, cell structural diversity, and classification of the protozoan phyla Loukozoa, Sulcozoa, and Choanozoa. European Journal of Protistology 49: 115-178

Cohen, P.A. and A.H. Knoll. (2012). Neoproterozoic scale microfossils from the Fifteen Mile Group,Yukon Territory. Journal of Paleontology 86: 775-800.

Cuthill, J.F.H., and S. Conway Morris (2014) Fractal branching organizations of Ediacaran rangeomorph fronds reveal a lost Proterozoic body plan. Proceedings of the National Academy of Sciences, USA 111: 13122-13126.

Dahl, T.W., E. Hammarlund, B.C. Gill, A.H. Knoll, A.D. Anbar, G.W. Gordon, D.P.G. Bond, N.H. Schovsbo, A.T. Nielsen, and D.E. Canfield. (2010). Devonian rise in atmospheric oxygen correlated to the radiations of terrestrial plants and large predatory fish. Proceedings of the National Academy of Sciences, USA 107: 17853-18232.

Dalton, L.A., T. Bosak, F.A. Macdonald, D.J.G. Lahr, and S.B. Pruss. (2013). Preservational and morphological variability of assemblages of agglutinated eukaryotes in Cryogenian cap carbonates of northern Namibia. Palaios 28: 67-79.

Deschamps, P., and D Moreira. (2009). Signal conflicts in the phylogeny of the primary photosynthetic eukaryotes. Molecular Biology and Evolution, 26: 2745-2753.

Eme, L., S.C. Sharpe, M.W. Brown, and A.J. Roger. (2014). On the age of eukaryotes: Evaluating evidence from fossils and molecular clocks. Cold Spring Harbor Perspectives in Biology, doi: 10.1101/cshperspect.a016139.

Erwin, D.H., and J. Valentine (2013) The Cambrian Explosion: The Construction of Animal Biodiversity. Roberts, Framingham MA, 416 pp.

Erwin, D.H., M. Laflamme, S.M.Tweedt, E.A. Sperling, D. Pisani, and K.J. Peterson. (2011). The Cambrian conundrum: Early divergence and later ecological success in the early history of animals. Science 334: 1091-1097.

Frei, R., C. Gaucher, S.W. Poulton, and D.E. Canfield (2009). Fluctuations in Precambrian atmospheric oxygenation recorded by chromium isotopes. Nature 461: 250-253.

M. Groussin, J. Pawlowski, and Z. Yang. (2011). Bayesian relaxed clock estimation of divergence times in foraminifera. Molecular Biology and Evolution 61: 157-166.

Hess, S., N. Sausen, and M. Melkonian. (2012). Shedding light on vampires: the phylogeny of vampyrellid amoebae revisited. PLoS ONE 7 (2): e31165. doi:10.1371/journal.pone.0031165.

Hessen, D.O., and E. Van Donk. (1993). Morphological changes in Scenedesmus induced by substances released by Daphnia. Archiv für Hydrobiologie 127: 129-140. 
Javaux E.J. (2011). Evolution of early eukaryotes in Precambrian oceans. In M. Gargaud, P. Lopez-Garcia, and H. Martin (eds), Origins and Evolution of Life: an Astrobiology Perspective (pp. 414-449). Cambridge: Cambridge University Press.

Javaux, E.J. and A.H. Knoll. (2015). Micropaleontology of the Lower Mesoproterozoic Roper Group, Australia. and implications for early eukaryotic evolution . Journal of Paleontology, in review.

Javaux, E., A.H. Knoll, and M.R. Walter. (2004). TEM evidence for eukaryotic diversity in midProterozoic oceans. Geobiology 2: 121-32.

Jeong, H.J., Y.D. Yoo, J.S. Kim, K.A. Seong, N.S. Kang, and T.H. Ki. (2010). Growth, feeding and ecological roles of the mixotrophic and heterotrophic dinoflagellates in marine planktonic food webs. Ocean Science Journal 45: 65-91.

Johnston, D.T., T. Goldberg, S.W. Poulton, V.N. Sergeev, V. Podkovyrov, N.G. Vorob’eva, A. Bekker, and A.H. Knoll. (2012). Late Ediacaran redox stability and metazoan diversification. Earth and Planetary Science Letters 335-336: 25-35.

Knoll, A.H. (2011). The multiple origins of complex multicellularity. Annual Review of Earth and Planetary Sciences 39: 217-239.

Knoll, A.H. (2014). Paleobiological perspectives on early eukaryotic evolution. Cold Spring Harbor Perspectives in Biology, doi: 10.1101/cshperspect.a016121.

Knoll, A.H., E.J. Javaux, D. Hewitt, and P. Cohen. (2006). Eukaryotic organisms in Proterozoic oceans. Philosophical Transactions of the Royal Society B 361: 1023-1038.

Knoll, A.H., R.E. Summons, J. Waldbauer, and J. Zumberge (2007). The geological succession of primary producers in the oceans. In: P. Falkowski and A.H. Knoll, eds., The Evolution of Primary Producers in the Sea. Burlington, Elsevier, pp. 133-163.

Laflamme, M, S. Xiao, and M. Kowalewski. (2009). Osmotrophy in modular Ediacara organisms. Proceedings of the National Academy of Sciences, USA 106: 14438-14443.

Lahr, D. and A.H. Knoll. (2015). Reconstructing the early evolution of feeding mode in eukaryotes. American Naturalist, in review.

Lan, Z., X. Li, Z.Q. Chen, Q. Li, A. Ofmann, Y. Zhang,Y. Liu, G. Tang, X. Ling, and J. Li. (2014). Diagenetic xenotime age constraints on the Sanjiaotang Formation, Luoyu Group, southern margin of the North China Craton: Implications for regional stratigraphic correlation and early evolution of eukaryotes. Precambrian Research 251: 21-32.

Levin, L.A. (2003). Oxygen Minimum Zone benthos: adaptation and community response to hypoxia. Oceanography and Marine Biology: an Annual Review 41: 1-45.

Lyons, T.W., C.T. Reinhard, and N.J. Planavsky. (2014). The rise of oxygen in Earth's early ocean and atmosphere. Nature 506: 307-315. 
Mikhailov, K.V., A.V. Konstantinova, M.A. Nikitin, V. Troshin, L.Yu. Rusin, V.A. Lyubetsky, et al. (2009). The origin of Metazoa: a transition from temporal to spatial cell differentiation.

BioEssays, 31: 758-68.

Mills, D.B. and D.E. Canfield. (2014). Oxygen and animal evolution: Did a rise of atmospheric oxygen trigger the origin of animals? BioEssays 36: 1-11.

Mills, D.B., L.M. Ward, C. Jones, B. Sweeten, M. Forth, A.H. Treusch, and D.E. Canfield. (2014). Oxygen requirements of the earliest animals. Proceedings of the National Academy of Sciences, USA 111: 4168-4172.

Pagel, M., A. Meade, and D. Barker. (2004) Bayesian estimation of ancestral character states on phylogenies. Systematic Biology 53: 673-684.

Parfrey, L.W. and D.J.G. Lahr. (2013). Multicellularity arose several times in the evolution of eukaryotes (Response to DOI 10.1002/bies. 201100187). BioEssays 35: 339-347.

Parfrey, L., D. Lahr, A.H. Knoll, and L.A. Katz. (2011). Estimating the timing of early eukaryotic diversification with multigene molecular clocks. Proceedings of the National Academy of Sciences, USA 108: 13624-13629

Planavsky N.J., C.T. Reinhard, X. Wang, D. Thompson, P. McGoldrick, R.H. Rainbird, T. Johnson, W.W. Fischer, and T.W. Lyons. (2014). Low mid-Proterozoic atmospheric oxygen levels and the delayed rise of animals. Science, 346: 635-638.

Porter, S.M. (2011) The rise of predators. Geology 39: 607-608.

Porter, S.M. and A.H. Knoll. (2000). Testate amoebae in the Neoproterozoic Era: evidence from vase-shaped microfossils in the Chuar Group, Grand Canyon. Paleobiology 26: 360-385.

Porter, S.M., R. Meisterfeld, and A.H. Knoll. (2003). Vase-shaped microfossils from the Neoproterozoic Chuar Group, Grand Canyon: a classification guided by modern testate amoebae. Journal of Paleontology 77: 205-25.

Ratti, S., A.H. Knoll and M. Giordano. (2013). Grazers and phytoplankton growth in the oceans: an experimental and evolutionary perspective. PLoS One 8(10): e77349.

doi:10.1371/journal.pone.0077349

Ronquist, F. (2004). Bayesian inference of character evolution. Trends in Ecology and Evolution 19: 475-481.

Sperling, E.A., and J. Vinther. (2010). A placozoan affinity for Dickinsonia and the evolution of late Proterozoic metazoan feeding modes. Evolution and Development 12: 201-209.

Sperling, E.A., G.P. Halverson, A.H. Knoll, F.A. Macdonald, and D.T. Johnston. (2013a). A basin redox transect at the dawn of animal life. Earth and Planetary Science Letters 371-372: 143-155. 
Sperling, E.A., C.A. Frieder, P.R. Girguis, A.V. Raman, L.A. Levin, and A.H. Knoll. (2013b). Oxygen, ecology, and the Cambrian radiation of animals. Proceedings of the National Academy of Sciences, USA 110: 13446-13451.

Srivastava M., E. Begovic, J. Chapman J, N.H. Putnam. U. Hellsten et al. (2008). The Trichoplax genome and the nature of placozoans. Nature 454: 955-960.

Strauss, J.V., A.D. Rooney, F.A. Macdonald, A.D. Brandon, and A.H. Knoll (2014) Circa 740 Ma vase-shaped microfossils from the Yukon Territory: Implications for Neoproterozoic biostratigraphy. Geology 42: 659-662.

Summons, R.E., and S.A. Lincoln. (2012). Biomarkers: Informative molecules for studies in geobiology. In A.H. Knoll, D.E. Canfield and K.O. Konhauser (eds), Fundamentals of Geobiology (pp. 269-296) Chicester, UK: Wiley-Blackwell.

Summons, R.E., S.C Brassell, G. Eglinton, E.J. Evans, R.J. Horodyski, N. Robinson, and D.M. Ward (1988). Distinctive hydrocarbon biomarkers from fossiliferous sediment of the late Proterozoic Walcott Member, Chuar Group, Grand Canyon, U.S.A. Geochimica et Cosmochimica Acta 52: 2625-2673.

Takishita, K., Y. Chikaraishi, M.M. Leger, E. Kim, A. Yabuki, N. Ohkouchi, and A.J. Roger. (2012). Lateral transfer of tetrahymanol-synthesizing genes has allowed multiple diverse eukaryote lineages to independently adapt to environments without oxygen. Biology Direct, 7(5), http://www.biology-direct.com/content/7/1/5.

Ventura, G.T., F. Kenig, E. Grosjean, and R.E. Summons. (2005). Biomarker analysis of extractable organic matter from the Neoproterozoic Kwagunt Formation, Chuar Group ( 800$742 \mathrm{Ma}) . \mathrm{Ma})$. Fall AGU meeting abstracts.

Wenderoth, H. (1986). Transepithelial cytophagy by Trichoplax adhaerens FE Schulze (Placozoa) feeding on yeast. Zeitschrift für Naturforschung. Section C, Biosciences 41: 343-347.

Xiao, S., A.H. Knoll, A.J. Kaufman, L. Yin, and Y. Zhang (1997). Neoproterozoic fossils in Mesoproterozoic rocks? Chemostratigraphic resolution of a biostratigraphic conundrum from the North China Platform. Precambrian Research 84: 197-220.

Xiao, S.H., X.L. Yuan, M. Steiner, and A.H. Knoll. (2002). Macroscopic carbonaceous compressions in a terminal Proterozoic shale: A systematic reassessment of the Miaohe biota, south China. Journal of Paleontology 76: 347-376.

Yin, L. (1997). Acanthomorphic acritarchs from Meso-Neoproterozoic shales of the Ruyang Group, Shanxi, China. Review of Palaeobotany and Palynology 98: 15-25.

Yuan, X., Z. Chen, S. Xiao (2011). An early Ediacaran assemblage of macroscopic and morphologically differentiated eukaryotes. Nature 470: 390-393. 

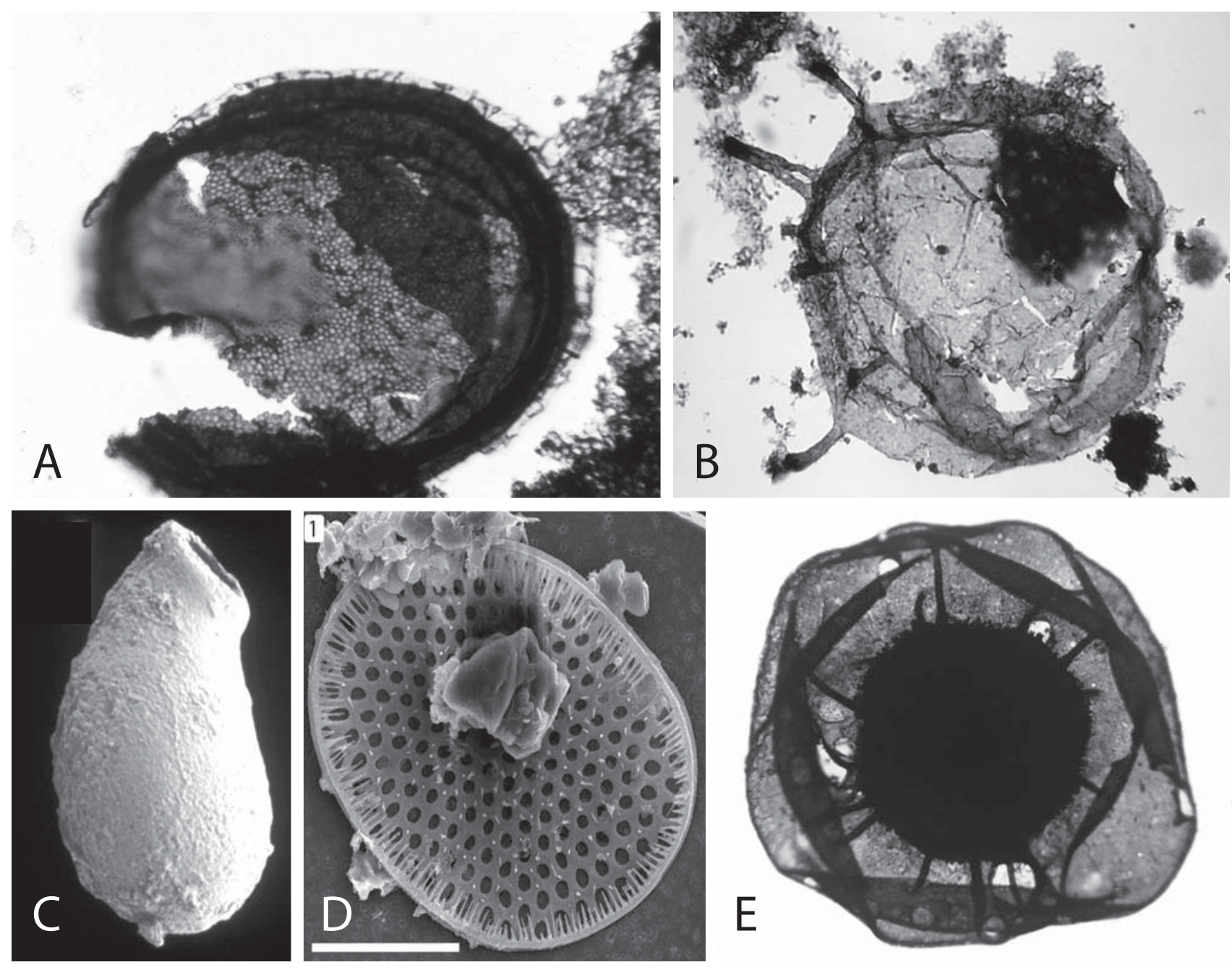
